\title{
Gangue mineral textures and fluid inclusion characteristics of the Santa Margarita Vein in the Guanajuato Mining District, Mexico
}

Research Article

\author{
Daniel Moncada, Robert J. Bodnar
}

Department of Geosciences,

Virginia Tech, Blacksburg, VA 24061 USA

Received 31 October 2011 ; accepted 8 February 2012

\begin{abstract}
Successful exploration for mineral deposits requires tools that the explorationist can use to distinguish between targets with high potential for mineralization and those with lower economic potential. In this study, we describe a technique based on gangue mineral textures and fluid inclusion characteristics that has been applied to identify an area of high potential for gold-silver mineralization in the epithermal Ag-Au deposits at Guanajuato, Mexico. The Guanajuato mining district in Mexico is one of the largest silver producing districts in the world with continuous mining activity for nearly 500 years. Previous work conducted on the Veta Madre vein system that is located in the central part of this district identified favorable areas for further exploration in the deepest levels that have been developed and explored. The resulting exploration program discovered one of the richest gold-silver veins ever found in the district. This newly discovered vein that runs parallel to the Veta Madre was named the Santa Margarita vein. Selected mineralized samples from this vein contain up to $249 \mathrm{~g} / \mathrm{t}$ of $\mathrm{Au}$ and up to $2,280 \mathrm{~g} / \mathrm{t}$ Ag. Fluid inclusions in these samples show homogenization temperatures that range from 184 to $300^{\circ} \mathrm{C}$ and salinities ranging from 0 to $5 \mathrm{wt} . \% \mathrm{NaCl}$. Barren samples show the same range in homogenization temperature, but salinities range only up to $3 \mathrm{wt} . \% \mathrm{NaCl}$. Evidence of boiling was observed in most of the samples based on fluid inclusions and/or quartz and calcite textures. Liquid-rich inclusions with trapped illite are closely associated with high silver grades. The presence of assemblages of vapor-rich-only fluid inclusions, indicative of intense boiling or "flashing", shows the best correlation with high gold grades.

Keywords: Guanajuato Mining District $•$ Veta Madre $\cdot$ fluid inclusions $•$ boiling $\bullet$ flashing $\cdot$ mineral exploration $\bullet$ epithermal precious metals deposits

(C) Versita Sp. z o.o.
\end{abstract}

\section{Introduction}

The Guanajuato Mining District (GMD) in Mexico is one of the largest silver producing districts in the world with continuous mining activity for nearly 500 years. The epithermal deposits in the GMD are hosted by steeply dipping quartz \pm carbonate veins that show mineralization over vertical extents of several hundreds of meters. In re- cent years, there has been much activity in the GMD to explore for additional resources below the known levels of mineralization.

Previous detailed studies of the Veta Madre have documented a strong correlation between boiling and silver and gold deposition [1, 2]. In a recently completed study [1] of the Veta Madre vein system, fluid inclusion and gangue mineral textures were examined in 855 samples. Min- 
eral textures and fluid inclusion features characteristic of fluid immiscibility or boiling, including colloform quartz, plumose/feathery/flamboyant quartz, lattice-bladed calcite and lattice-bladed calcite replaced by quartz, as well as coexisting liquid-rich and vapor-rich fluid inclusions and assemblages of vapor-rich only inclusions, were recognized in samples from the Veta Madre. Most samples studied were assayed for $\mathrm{Au}$ and $\mathrm{Ag}$, and were divided into ore grade and sub-economic samples based on the gold and silver concentrations. For silver, samples containing $>100$ ppm were classified as ore grade, and for Au samples containing $>1 \mathrm{ppm}$ were considered to be ore grade. The feature that was most closely associated with ore grades of both gold and silver is colloform quartz that was originally precipitated as amorphous silica, and this feature also showed the largest difference in average grade between samples that display colloform texture (178.8 ppm $\mathrm{Ag}$ and $1.1 \mathrm{ppm} \mathrm{Au}$ ) and those that do not exhibit this texture (17.2 ppm $\mathrm{Ag}$ and $0.2 \mathrm{ppm} \mathrm{Au})$. Statistical analysis of the data indicated that colloform quartz is the feature that has the greatest predictive power for distinguishing between ore grade and sub-economic samples.

In the study by Moncada et al. [1], evidence of boiling was present in nearly all samples examined, including those from the deepest levels of exploration and production in the mines. Moreover, samples collected from the surface and from drill core along a traverse perpendicular to the Veta Madre showed that evidence for boiling becomes more common and pervasive as mineralization is approached. With these results, a new drilling exploration program was undertaken in areas where the evidence for boiling was strongest and one of the richest gold-silver veins ever discovered in the $500+$ year mining history of the Guanajuato district was found [3]. This new vein, named the Santa Margarita vein, is the subject of this communication. For this study, gangue mineral textures and fluid inclusion characteristics in samples from the Santa Margarita vein were examined to document evidence for boiling of the hydrothermal fluids during formation of this rich ore zone.

\section{Evidence for boiling as a deposi- tional mechanism in epithermal pre- cious metals deposits}

Fluid inclusion studies of epithermal precious metals deposits and their modern analogs, active continental geothermal systems, document the genetic relationship between boiling and precious metal mineralization [4-12]. One of the earliest studies that described the relationship between fluid properties, silica precipitation and precious metal mineralization was by Weissberg, based on his work in the Taupo volcanic zone, New Zealand [13]. Similarly, Brown [10] documented the deposition of gold and silver as geothermal fluids passed through a pressure plate and "flashed" in drill hole BR22 at the Broadlands geothermal field, New Zealand. Seward [14] calculated the effect of boiling on gold-bearing fluids in the Ohaaki-Broadlands geothermal field and found that adiabatic flashing of the geothermal fluid between 290 and $277^{\circ} \mathrm{C}$ leads to quantitative precipitation of all gold in solution, whereas simple conductive cooling causes only minor gold deposition.

The observed relationship between gold and silver mineralization and boiling in active geothermal systems is consistent with theoretical and experimental studies of gold and silver solubility [15-18]. The solubility of gold as a bisulfide complex at $250^{\circ} \mathrm{C}$ and as a function of fluid $\mathrm{pH}$ and oxidation state is shown on Figure 1. Also shown on Figure 1 are the stability fields for the Fe-bearing phases hematite, pyrite, magnetite and pyrrhotite for a total sulfur activity of 0.01 , as well as the $\mathrm{H}_{2} \mathrm{~S}-\mathrm{HS}^{-}$and $\mathrm{HSO}_{4}^{-}-\mathrm{SO}_{4}^{2-}$ equilibrium boundaries. Also shown is neutral $\mathrm{pH}$ at $250^{\circ} \mathrm{C}$, based on the $\mathrm{pK}_{w}$ of $10^{-11.3}$ from Helgeson [15]. In most epithermal deposits, pyrite or an iron oxide phase, along with adularia and illite, are common gangue minerals [19]. We note that illite is found in association with quartz that was precipitated as crystalline quartz as well as with colloform quartz that was originally precipitated as amorphous silica. The illite-adularia equilibrium boundary is shown for equilibrium with both amorphous silica and quartz at $250^{\circ} \mathrm{C}$, assuming $\mathrm{K}^{+}$concentration of $5 \times 10^{-3} \mathrm{~m}$ and $\mathrm{Mg}^{2+}$ concentration of $4 \times 10^{-5} \mathrm{~m}$. Illite-adularia equilibria were calculated using data from Helgeson [15] combined with the data from Gunnarsson and Arnórsson [20] for quartz and amorphous silica equilibria. Note that the $\mathrm{pH}$ of a fluid in equilibrium with illite and adularia and precipitating quartz will decrease by greater than one $\mathrm{pH}$ unit if the fluid begins to precipitate amorphous silica in response to boiling, and will evolve from being slightly basic to slightly acidic (Fig. 1). This resulting decrease in $\mathrm{pH}$ can lead to a decrease in gold solubility by about 1-2 orders of magnitude and can cause gold to precipitate if the fluid before boiling was at or near gold saturation. This interpretation is consistent with Brown [21] who found that boiling, mixing with acid sulfate waters ( $\mathrm{pH}$ decrease) and mixing with oxygenated meteoric waters (increase in oxygen activity) all lead to gold deposition. Within the area bounded by the illite-adularia-amorphous silica and illite-adularia-quartz equilibria, and within the pyrite stability field, gold solubilities shown on Figure 1 range from about $1 \mathrm{ppb}$ to about $1 \mathrm{ppm}$, and are consistent with Au concentrations in deep geothermal waters in the Taupo Volcanic Zone 


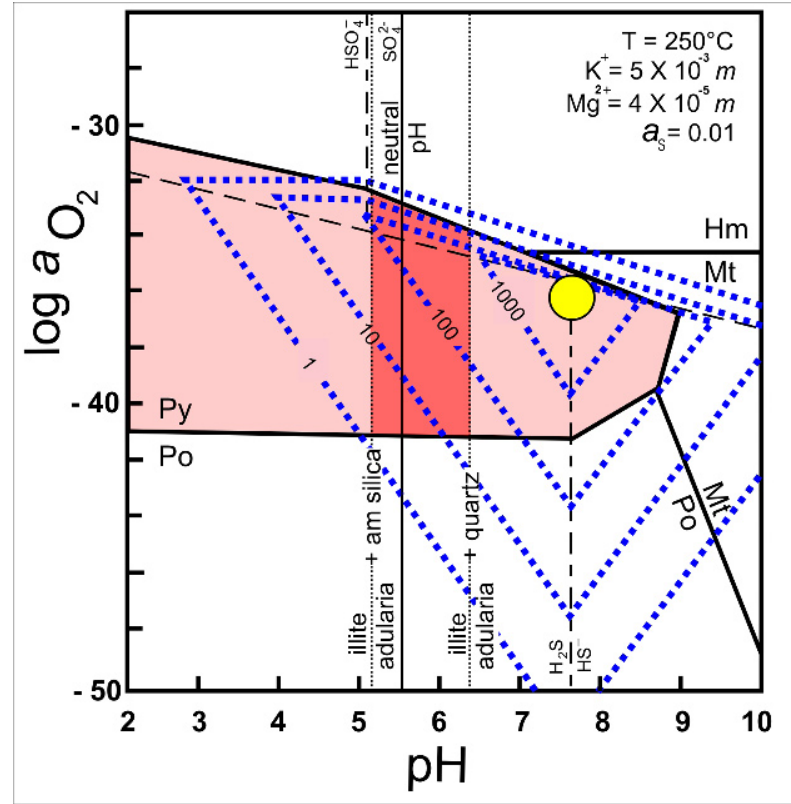

Figure 1. Solubility of Au as a function of the activity of oxygen and $\mathrm{pH}$. Maximum Au solubility is represented by the yellow circle, and gold solubility contours (in ppb) are shown by dashed lines. (modified from [43] and [16]).

$(<0.1-23 \mathrm{ppb} \mathrm{Au})$, at Lihir Island, Papua New Guinea (13-26 ppb Au) [22, 23], and in the La Primavera, Mexico, geothermal system (59 ppb Au) [24].

The mechanisms associated with gold and silver transport and deposition in the epithermal environment are well constrained based on recent experimental studies. Stefànsson and Seward [17] measured the solubility of gold in aqueous sulfide solutions from $100-500^{\circ} \mathrm{C}$ at 500 bars. These workers found that in the epithermal temperature range gold (I) sulfide complexes predominate and that boiling of both dilute and saline geothermal fluids leads to quantitative loss of gold from solution. Similarly, Stefànsson and Seward [18] measured the solubility of silver in aqueous sulfide solutions from $25-400^{\circ} \mathrm{C}$ and up to 500 bars. Based on their experimental results, these workers concluded that adiabatic boiling results in precipitation of silver sulfide. These experimental studies, combined with observations in active geothermal systems, provide overwhelming evidence that boiling is an effective mechanism to precipitate gold and silver from solution in the epithermal environment. This, combined with other studies that have correlated fluid inclusions [25] and mineral textures [26-29] with boiling processes, makes it possible to develop effective exploration models to distinguish between areas that have high probability for precious metal mineralization and those that are less likely to

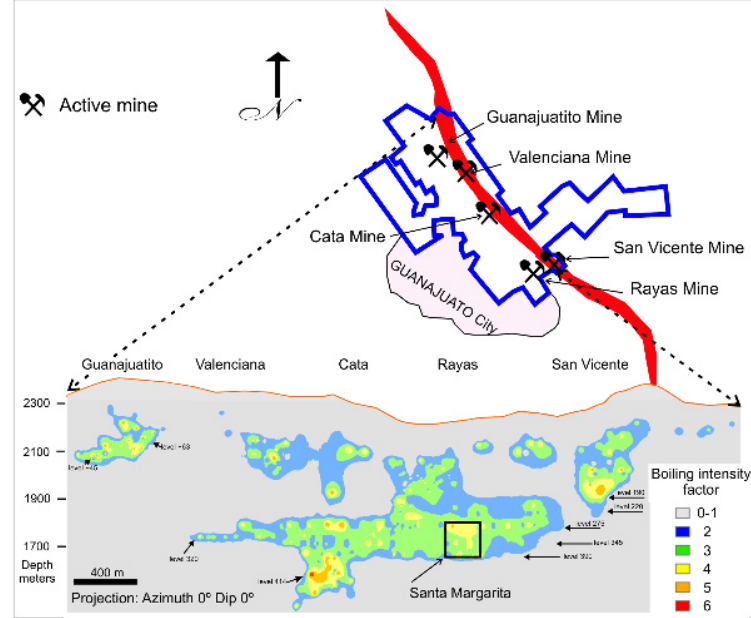

Figure 2. Location map of Veta Madre within the Guanajuato Mining District showing locations of mines (upper right). Longitudinal section of part of the Veta Madre showing the boiling intensity factor and location of Santa Margarita vein (box), (modified from [44] and [34]). The boiling intensity factor is defined as the number of textural and fluid inclusion boiling indicators observed in each sample, as described by Moncada et al. [1].

host such mineralization, as described in detail by Moncada et al. [1].

\section{Geologic setting}

The Santa Margarita vein is a hanging wall structure parallel to the main Veta Madre vein system that has been described in detail by many workers [2, 30-34]. In longitudinal section, the Santa Margarita vein occurs at about the same location along the Veta Madre as the Rayas Mine (Figure 2). The hanging wall in this area consists of Tertiary monomictic to polymictic conglomerates, breccias, sandstones and ash tuffs [33]. The vein is brecciated and cemented by quartz and lesser amounts of calcite. In the upper levels the mineralization consists of acanthite and base metals, whereas electrum is more abundant in the lower levels. We note that this distribution of metals is the opposite of what Buchanan [2] described at Guanajuato, and the opposite of what is generally observed in epithermal deposits [35]. We interpret the inverted metal distribution in the Santa Margarita vein to represent two different events, one in which the boiling horizon was somewhat above the level of the Sta. Margarita vein (thus, precipitating base metals at the level of the Sta. Margarita vein) and the other in which the boiling horizon was at or slightly below the level of the Sta. Margarita vein (thus precipitating gold at the level of the vein). 


\section{Methodology}

In collaboration with staff of Great Panther Silver Limited, 12 samples were collected from underground working areas, and from exploration drill holes that intersected the Santa Margarita vein "shoot", which is 52 meters long and 3.4 meters wide and about 18 meters high. The Santa Margarita vein is located close to and parallels the hanging wall of the Veta Madre. Samples were collected from the Santa Margarita vein near its footwall, near its hanging wall and from the interior of the vein, which is highly brecciated. The footwall on the Veta Madre has been documented to contain the highest grade gold-silver mineralization [34], and this relationship also holds for the Santa Margarita vein. Later drilling to a depth of 100 meters below where the samples for this study were collected identified mineralization containing up to $44.76 \mathrm{~g} / \mathrm{t}$ gold and $46 \mathrm{~g} / \mathrm{t}$ silver over a true width of 1.14 meters in drill hole UGSM11-005 [36].

One half of each sample collected was assayed for gold $(\mathrm{Au})$, silver $(\mathrm{Ag})$, copper $(\mathrm{Cu})$, lead $(\mathrm{Pb})$, zinc $(\mathrm{Zn})$, arsenic (As) and antimony (Sb), and the other half was used to prepare a polished section to examine mineral textures and fluid inclusions. The samples contain from 0.0017 to $249 \mathrm{~g} / \mathrm{t} \mathrm{Au}$, and from $<3$ to $2,280 \mathrm{~g} / \mathrm{t} \mathrm{Ag}$. Samples that were high in silver contained galena and sphalerite, whereas there was no evidence of base metals, arsenic or antimony for samples that contain electrum. All hand samples were cut perpendicular to the vein to produce a section that extended from the vein wall towards the center of the vein, and a standard doubly-polished thin section was prepared for fluid inclusions petrography.

\section{Petrography}

Polished thin sections were examined using a petrographic microscope to identify the minerals present and to classify the textures of quartz and calcite (every sample contained quartz and five also contained calcite, and three contained rhombic adularia). The mineral texture classifications that have been observed in the Guanajuato deposits and their interpretations in terms of the physical state of the fluid (boiling vs. non-boiling) have been described in detail elsewhere [1]. Next, the sample was examined systematically to identify fluid inclusion assemblages (FIAs) and the types of fluid inclusions in each FIA were noted. An FIA represents a group of fluid inclusions that were all trapped at the same time $[37,38]$. FIAs may contain primary inclusions trapped during precipitation of the host phase, or may contain secondary inclusions that were trapped along fractures in the host phase at some time after the

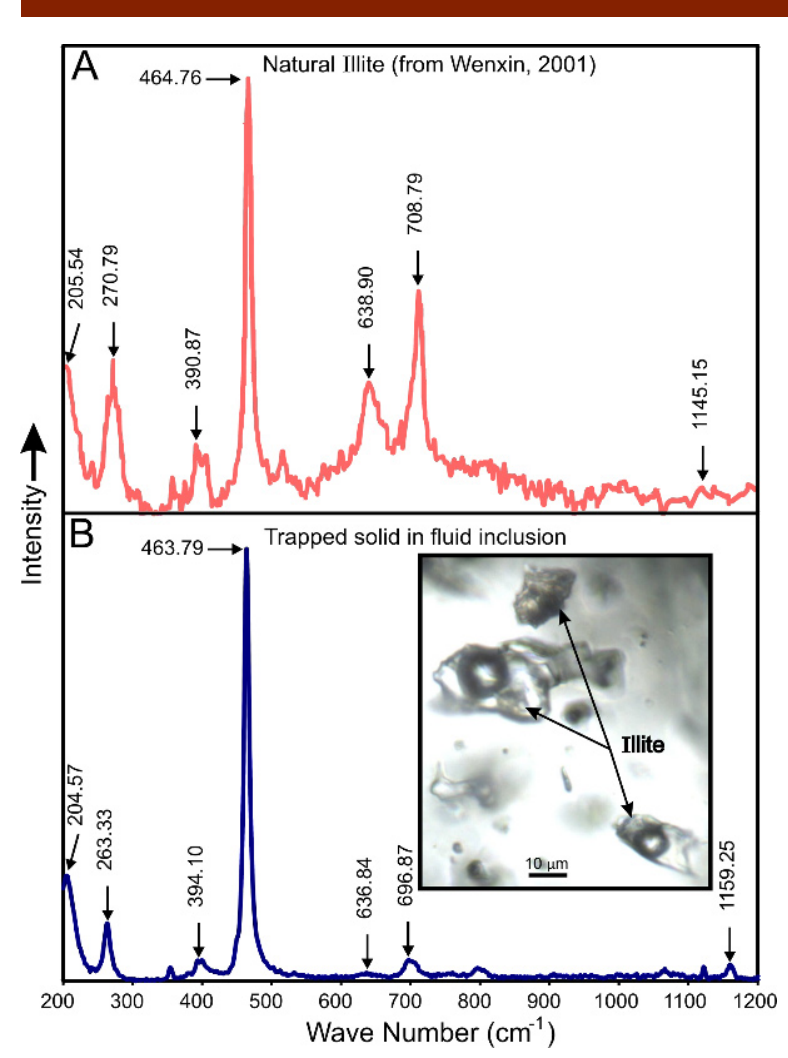

Figure 3. Raman spectra of a natural illite [45] (top) and a solid phase that occurs in fluid inclusions (bottom) from the Santa Margarita vein at Guanajuato, Mexico. The inset in the bottom spectrum shows three illite-bearing fluid inclusions in quartz.

mineral formed. It is important to mention that fluid inclusions contained in some quartz and calcite textures do not record original conditions of formation [1, 25, 28]. This applies mostly to quartz that was originally precipitated as amorphous silica and later recrystallized to quartz, and to bladed calcite that was later replaced by quartz.

FIAs in samples from Santa Margarita were further classified as containing (1) only liquid-rich inclusions with consistent liquid-to-vapor ratios, (2) liquid-rich inclusions with consistent liquid-to-vapor ratios and containing a trapped illite crystal, (3) coexisting liquid-rich and vaporrich inclusions with a broad range in liquid-to-vapor ratios, and (4) assemblages consisting of only vapor-rich inclusions. The illite phase in liquid-rich inclusions was identified based on Raman analysis and is interpreted to represent a trapped solid because its distribution within the inclusions comprising an FIA is not uniform, and the relative size of the illite varies greatly within the FIA (Figure 3).

Following detailed petrographic examination of the samples, 58 FIAs were selected for microthermometric 
analysis. Inclusions were measured using a Linkam THMSG $600^{\circ} \mathrm{C}$ heating stage mounted on a standard petrographic microscope. The stage was calibrated using synthetic fluid inclusion standards [39]. The precision and accuracy of measured homogenization temperatures are estimated to be $\pm 1.0^{\circ} \mathrm{C}$ and the precision and accuracy of ice-melting temperatures are estimated to be $\pm 0.1^{\circ} \mathrm{C}$.

\section{Data and results}

The goal of this study was to document the different gangue mineral textures and fluid inclusion types in samples from the gold- and silver-rich Santa Margarita vein in the Guanajuato Mining District to test the hypothesis that gold and silver deposition was associated with boiling. The Santa Margarita vein represents a bonanza deposit and previous experimental studies and studies of both active and fossil epithermal systems suggest that boiling is commonly the mechanism of deposition in these deposits. Several mineral textures observed in the Santa Margarita samples, including jigsaw texture quartz, plumose texture quartz, colloform texture quartz, lattice bladed calcite, colloform-banded plumose texture, colloform-banded jigsaw texture, and lattice-bladed calcite replaced by quartz (Figure 4), are consistent with rapid mineral precipitation as a result of boiling [26-29]. In addition, the presence of coexisting liquid-rich and vapor-rich fluid inclusions in the same FIA indicates that the inclusions were trapped from a boiling fluid.

The homogenization temperatures of fluid inclusions from mineralized samples range from 184 to $300^{\circ} \mathrm{C}$ and icemelting temperatures correspond to salinities between 0 and 5 wt.\% $\mathrm{NaCl}$ [40] (Figure 5). Barren samples show the same range in homogenization temperature but with a slightly lower maximum salinity of 3 wt.\% $\mathrm{NaCl}$ (Figure 5). There does not appear to be a strong correlation between homogenization temperature and/or salinity and the presence or absence of ore grade mineralization.

Fluid Inclusion Assemblages consisting of coexisting liquid-rich and vapor-rich fluid inclusions show no trend in homogenization temperatures, but salinities of inclusions in these FIAs are always $<2 w t \% \mathrm{NaCl}$. FIAs that consist of fluid inclusions that contain trapped illite homogenize over a relatively narrow range from about 270$300^{\circ} \mathrm{C}$, with salinities between 1-2 wt\% $\mathrm{NaCl}$. One FIA in adularia was identified, and these inclusions had a noticeably lower homogenization temperature $\left(\approx 185^{\circ} \mathrm{C}\right)$ and higher salinity (>3 wt\%) compared to most other FIAs in other minerals. FIAs consisting of coexisting liquid-rich and vapor rich inclusions in bladed calcite homogenize from about $240-260^{\circ} \mathrm{C}$, and have low salinities $(<1 \mathrm{wt} \%$

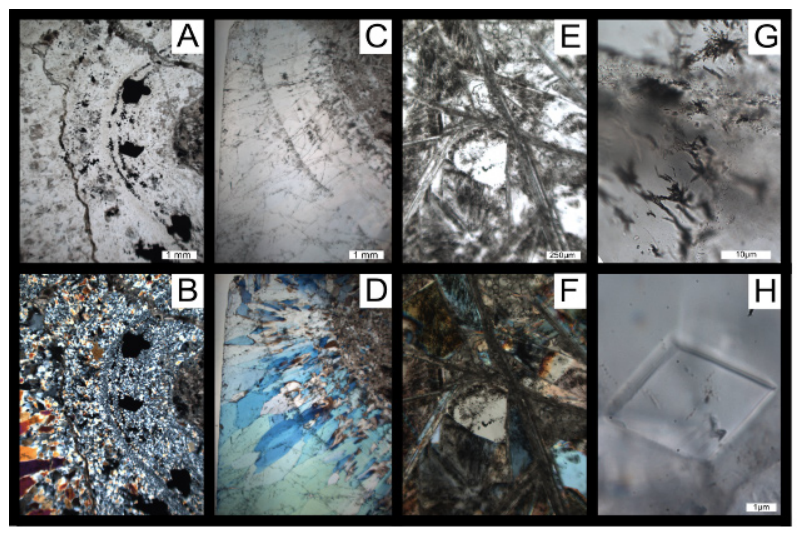

Figure 4. Examples of mineral textures observed in samples from the Santa Margarita Vein. (A) Colloform-banded jigsaw texture quartz; (B) Colloform-banded jigsaw texture quartz viewed under crossed nicols; (C) Colloformbanded plumose texture quartz; (D) Colloform-banded plumose texture quartz viewed under crossed nicols; (E) Lattice-bladed calcite replaced by quartz; (F) Latticebladed calcite replaced by quartz viewed under crossed nicols; (G) Illite inclusions in quartz; (H) Rhombic adularia in quartz

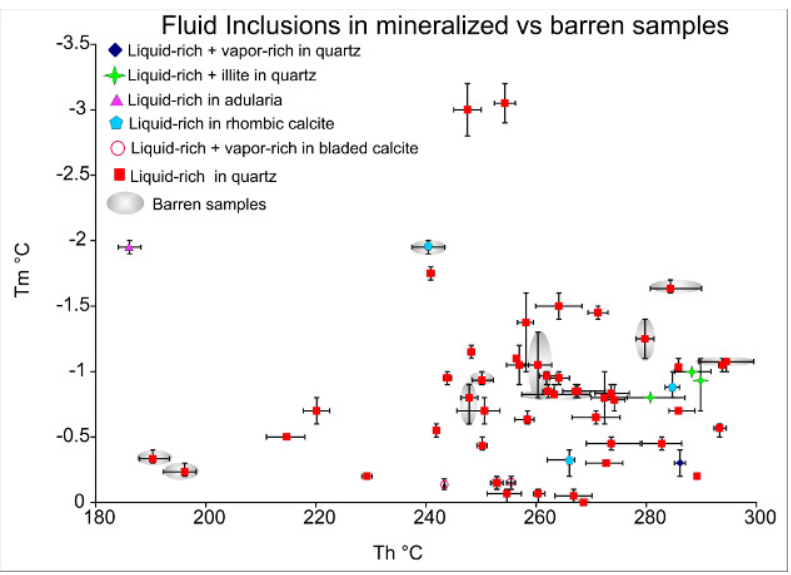

Figure 5. Homogenization temperature versus ice-melting temperature for 58 Fluid Inclusion Assemblages (FIAs) in mineralized and barren samples from the Santa Margarita Vein. Each FIA consists of two or more fluid inclusions with consistent microthermometric behavior.

$\mathrm{NaCl}$ ). FIAs consisting of only liquid-rich inclusions in rhombic calcite homogenize at $240-300^{\circ} \mathrm{C}$, with salinities from about $1-3 w t \% \mathrm{NaCl}$. It should be noted that no FIAs consisting of either coexisting liquid-rich and vapor rich inclusions, or vapor-rich inclusions only, were found in the rhombic calcite, and this is consistent with previous studies that have shown that rhombic calcite is not associated with boiling fluids [4]. Table 1 summarizes the microthermometric data for samples from the Santa Margarita vein. 
Table 1. Microthermometric data for fluid inclusions from the Santa Margarita vein.

\begin{tabular}{|c|c|c|c|c|c|c|c|c|c|c|}
\hline Sample ID & Host & Type & $n$ & $\mathrm{~T}_{h}$ range $\left({ }^{\circ} \mathrm{C}\right)$ & Ave. & $\mathrm{T}_{m}$ range $\left({ }^{\circ} \mathrm{C}\right)$ & Ave. & wt.\% $\mathrm{NaCl}$ equiv 1 & Ave. & Notes \\
\hline $2001-123$ & Quartz & $\mathrm{S}$ & 3 & $292.3-294.5$ & 293.3 & -0.6 to -0.5 & -0.6 & $0.9-1.1$ & 1.0 & Liquid-rich;2001-123B-IV_1FIA \\
\hline $2001-123$ & Quartz & $\mathrm{S}$ & 2 & $267.1-267.2$ & 267.2 & -0.9 to -0.8 & -0.9 & $1.4-1.6$ & 1.5 & Liquid-rich;2001-123B-IV_2FIA \\
\hline $2001-123$ & Quartz & $\mathrm{S}$ & 3 & $211-218$ & 214.7 & -0.5 to -0.5 & -0.5 & $0.9-0.9$ & 0.9 & Liquid-rich;2001-123B-IV_3FIA \\
\hline $2001-123$ & Quartz & $\mathrm{S}$ & 2 & $289-289.4$ & 289.2 & -0.2 to -0.2 & -0.2 & $0.4-0.4$ & 0.4 & Liquid-rich;2001-123B-II_1FIA \\
\hline 2001-123 & Quartz & $\mathrm{S}$ & 4 & $245.6-253.4$ & 250.6 & -0.8 to -0.6 & -0.7 & $1.1-1.4$ & 1.2 & Liquid-rich;2001-123B-VII_1FIA \\
\hline $2001-123$ & Quartz & $\mathrm{S}$ & 3 & $256.1-259.6$ & 258.4 & -0.7 to -0.6 & -0.6 & $1.1-1.2$ & 1.1 & Liquid-rich;2001-123B-VII_2FIA \\
\hline $2001-123$ & Quartz & $\mathrm{S}$ & 3 & $255.9-256.8$ & 256.4 & -1.1 to -1.1 & -1.1 & $1.9-1.9$ & 1.9 & Liquid-rich;2001-123B-VII_3FIA \\
\hline $2001-123$ & Quartz & $\mathrm{S}$ & 3 & $251.1-257.3$ & 254.7 & -0.1 to 0 & -0.1 & $0-0.2$ & 0.1 & Liquid-rich;2001-123B-VII_5FIA \\
\hline $2001-123$ & Quartz & $\mathrm{S}$ & 3 & $284.1-288.8$ & 285.8 & -0.7 to -0.7 & -0.7 & $1.2-1.2$ & 1.2 & Liquid-rich;2001-123B-VII_7FIA \\
\hline 1015917 & Quartz & $\mathrm{S}$ & 4 & $269.1-278.9$ & 273.6 & -0.5 to -0.4 & -0.5 & $0.7-0.9$ & 0.8 & Liquid-rich;1015917 IV_1FIA \\
\hline 1015917 & Quartz & $\mathrm{S}$ & 3 & $269-275.7$ & 272.7 & -0.3 to -0.3 & -0.3 & $0.5-0.5$ & 0.5 & Liquid-rich;1015917 IV_2FIA \\
\hline 1015917 & Quartz & $\mathrm{S}$ & 3 & $289.7-289.9$ & 289.8 & -1.1 to -0.7 & -0.9 & $1.2-1.9$ & 1.6 & Liquid-rich + illite;1015917 I_1FIA_Illite \\
\hline 1015918 & Calcite & $\mathrm{S}$ & 5 & $283.4-286$ & 284.8 & -1 to -0.8 & -0.9 & $1.4-1.7$ & 1.5 & Liquid-rich;1015918B_Calcite \\
\hline 1015918 & Quartz & $\mathrm{S}$ & 2 & $293.1-294.5$ & 293.8 & -1.1 to -1 & -1.1 & $1.7-1.9$ & 1.8 & Liquid-rich;1015918B_3FIA \\
\hline 1015918 & Quartz & $\mathrm{S}$ & 2 & $266.5-275.2$ & 270.9 & -0.7 to -0.6 & -0.7 & $1.1-1.2$ & 1.1 & Liquid-rich;1015918B_4FIA \\
\hline $2001-122$ & Quartz & $\mathrm{S}$ & 2 & $285.1-287.1$ & 286.1 & -0.4 to -0.2 & -0.3 & $0.4-1.7$ & 1.1 & Liquid-rich + Vapor-rich;2001-122B-II 2FIA LV \\
\hline $2001-122$ & Quartz & $\mathrm{S}$ & 3 & $260.6-263.6$ & 261.9 & -1 to -0.9 & -1.0 & $1.6-1.7$ & 1.7 & Liquid-rich;2001-122B_1FIA \\
\hline 1015919 & Calcite & $\mathrm{S}$ & 4 & $262-267$ & 266.0 & -0.4 to -0.2 & -0.3 & $0.4-0.7$ & 0.6 & Liquid-rich;105919AI_Calcite \\
\hline 105920 & Quartz & $\mathrm{S}$ & 4 & $262.5-266$ & 264.1 & -1 to -0.9 & -1.0 & $1.6-1.7$ & 1.7 & Liquid-rich;105920 IV_3FIA \\
\hline 105920 & Quartz & $\mathrm{S}$ & 3 & $285.4-286.2$ & 285.8 & -1.1 to -1 & -1.0 & $1.7-1.9$ & 1.8 & Liquid-rich;105920 IV_2FIA \\
\hline 105921 & Calcite & $\mathrm{S}$ & 5 & $243.1-243.5$ & 243.3 & -0.2 to -0.1 & -0.1 & $0.2-0.2$ & 0.2 & Liquid-rich + Vapor-rich;105921_III_1FIA_BC \\
\hline 105921 & Calcite & $\mathrm{S}$ & 4 & $254.6-256.2$ & 255.5 & -0.2 to -0.1 & -0.2 & $0.2-0.4$ & 0.3 & Liquid-rich + Vapor-rich;105921_III_3FIA_BC \\
\hline 2001-125 & Quartz & $\mathrm{S}$ & 6 & $254.6-258.6$ & 256.9 & -1.2 to -0.9 & -1.1 & $1.6-2.1$ & 1.8 & Liquid-rich;2001-125I_4FIA \\
\hline $2001-125$ & Quartz & $\mathrm{S}$ & 6 & $270-276.5$ & 272.4 & -1 to -0.6 & -0.8 & $1.1-1.7$ & 1.4 & Liquid-rich;2001-125I_3FIA \\
\hline $2001-125$ & Quartz & $\mathrm{P}$ & 5 & $256.6-259.5$ & 258.1 & -1.6 to -1 & -1.4 & $1.7-2.7$ & 2.4 & Liquid-rich;2001-125I_1FIA \\
\hline $2001-121$ & Quartz & $\mathrm{S}$ & 4 & $263.4-270.1$ & 266.8 & -0.1 to 0 & -0.1 & $0-0.2$ & 0.1 & Liquid-rich;2001-121I_2FIA \\
\hline $2001-124$ & Quartz & $\mathrm{S}$ & 3 & $259.5-261.6$ & 260.4 & -0.1 to 0 & -0.1 & $0-0.2$ & 0.1 & Liquid-rich;2001-124III_1FIA \\
\hline $2001-121$ & Quartz & $\mathrm{S}$ & 2 & $228.3-230.2$ & 229.3 & -0.2 to -0.2 & -0.2 & $0.4-0.4$ & 0.4 & Liquid-rich;2001-121III_3FIA \\
\hline 105919 & Quartz & $\mathrm{S}$ & 2 & $279.2-286.4$ & 282.8 & -0.5 to -0.4 & -0.5 & $0.7-0.9$ & 0.8 & Liquid-rich;105919III_4FIA \\
\hline 105919 & Quartz & $\mathrm{S}$ & 3 & $270.7-276.9$ & 273.6 & -0.9 to -0.8 & -0.8 & $1.4-1.6$ & 1.5 & Liquid-rich;105919III_5FIA \\
\hline 2001-125 & Quartz & $\mathrm{S}$ & 3 & $273-287$ & 281.0 & -0.8 to -0.8 & -0.8 & $1.4-1.4$ & 1.4 & Liquid-rich + illite;2001-125III_6FIA \\
\hline $2001-125$ & Quartz & $\mathrm{S}$ & 2 & $259.9-268.3$ & 264.1 & -1.6 to -1.4 & -1.5 & $2.4-2.7$ & 2.6 & Liquid-rich;2001-125III_7FIA \\
\hline $2001-125$ & Quartz & $\mathrm{S}$ & 2 & $269.4-273$ & 271.2 & -1.5 to -1.4 & -1.5 & $2.4-2.4$ & 2.4 & Liquid-rich;2001-125III_7FIA \\
\hline 2001-125 & Quartz & $\mathrm{S}$ & 6 & $272-276.1$ & 274.2 & -0.9 to -0.7 & -0.8 & $1.2-1.6$ & 1.4 & Liquid-rich;2001-125II-II \\
\hline $2001-125$ & Quartz & $\mathrm{S}$ & 2 & $252.4-256.2$ & 254.3 & -3.2 to -2.9 & -3.1 & $4.8-5.3$ & 5.0 & Liquid-rich;2001-125B-IV_2FIA \\
\hline $2001-125$ & Quartz & $\mathrm{S}$ & 2 & $245-250$ & 247.5 & -3.2 to -2.8 & -3.0 & $4.6-5.3$ & 5.0 & Liquid-rich;2001-125B-IV_3FIA \\
\hline $2001-125$ & Quartz & $\mathrm{S}$ & 2 & $247.6-248.8$ & 248.2 & -1.2 to -1.1 & -1.2 & $1.9-2.1$ & 2.0 & Liquid-rich;2001-125B-IV_7FIA \\
\hline $2001-125$ & Quartz & $\mathrm{S}$ & 2 & $243.1-244.6$ & 243.9 & -1 to -0.9 & -1.0 & $1.6-1.7$ & 1.7 & Liquid-rich;2001-125B-IV_9FIA \\
\hline 2001-125 & Quartz & $\mathrm{S}$ & 3 & $241.5-242.2$ & 241.9 & -0.6 to -0.5 & -0.6 & $0.9-1.1$ & 1.0 & Liquid-rich;2001-125B-IV_12FIA \\
\hline $2001-125$ & Quartz & $\mathrm{s}$ & 2 & $261.2-263.1$ & 262.2 & -0.9 to -0.8 & -0.9 & $1.4-1.6$ & 1.5 & Liquid-rich;2001-125B-V_1FIA \\
\hline $2001-125$ & Quartz & $\mathrm{S}$ & 4 & $264.8-272.5$ & 267.6 & -0.9 to -0.8 & -0.9 & $1.4-1.6$ & 1.5 & Liquid-rich;2001-125A-V_1FIA \\
\hline $2001-125$ & Quartz & $\mathrm{S}$ & 2 & $240.2-241.5$ & 240.9 & -1.8 to -1.7 & -1.8 & $2.9-3.1$ & 3.0 & Liquid-rich;2001-125B-V_2FIA \\
\hline $2001-125$ & Quartz & $\mathrm{S}$ & 4 & $217.7-222.5$ & 220.1 & -0.8 to -0.6 & -0.7 & $1.1-1.4$ & 1.2 & Liquid-rich;2001-125A-II_1FIA \\
\hline $2001-125$ & Adularia & $\mathrm{S}$ & 2 & $184.1-188.2$ & 186.2 & -2 to -1.9 & -2.0 & $3.2-3.4$ & 3.3 & Liquid-rich;2001-125VI_1FIA Adularia \\
\hline $2001-126$ & Calcite & $\mathrm{S}$ & 3 & $237.4-243.4$ & 240.4 & -2 to -1.9 & -2.0 & $3.2-3.4$ & 3.3 & Liquid-rich;2001-126A_1FIA Calcite \\
\hline $2001-126$ & Quartz & $\mathrm{s}$ & 2 & $268.4-268.8$ & 268.6 & 0 to 0 & 0.0 & $0-0$ & 0.0 & Liquid-rich;2001-126A_3FIA \\
\hline $2001-126$ & Calcite & $\mathrm{S}$ & 3 & $280.7-290$ & 284.4 & -1.7 to -1.6 & -1.6 & $2.7-2.9$ & 2.8 & Liquid-rich;2001-126A_4FIA Calcite \\
\hline $2001-126$ & Quartz & $\mathrm{S}$ & 4 & $289.5-299.5$ & 294.5 & -1.1 to -1 & -1.1 & $1.7-1.9$ & 1.9 & Liquid-rich;2001-126_B_6FIA \\
\hline $2001-126$ & Quartz & $\mathrm{S}$ & 4 & $257.4-269.8$ & 263.3 & -0.9 to -0.8 & -0.8 & $1.4-1.6$ & 1.4 & Liquid-rich;2001-126_B_2FIA \\
\hline $2001-126$ & Quartz & $\mathrm{S}$ & 3 & $248.4-252.2$ & 250.1 & -1 to -0.9 & -0.9 & $1.6-1.7$ & 1.6 & Liquid-rich;2001-126_B_3FIA \\
\hline $2001-126$ & Quartz & $\mathrm{S}$ & 3 & 187.9-193.4 & 190.4 & -0.4 to -0.3 & -0.3 & $0.5-0.7$ & 0.6 & Liquid-rich;2001-126_B_1FIA \\
\hline $2001-126$ & Quartz & $\mathrm{S}$ & 3 & $192.3-198.2$ & 196.2 & -0.3 to -0.2 & -0.2 & $0.4-0.5$ & 0.4 & Liquid-rich;2001-126_B_2FIA \\
\hline $2001-126$ & Quartz & $\mathrm{S}$ & 2 & $251.7-254$ & 252.9 & -0.2 to -0.1 & -0.2 & $0.2-0.4$ & 0.3 & Liquid-rich;2001-126_C_1FIA \\
\hline $2001-126$ & Quartz & $\mathrm{S}$ & 2 & $257.8-262.8$ & 260.3 & -1.3 to -0.8 & -1.1 & $1.4-2.2$ & 1.8 & Liquid-rich;2001-126_C_2FIA \\
\hline $2001-126$ & Quartz & $S$ & 3 & $249.2-251.1$ & 250.2 & -0.5 to -0.4 & -0.4 & $0.7-0.9$ & 0.8 & Liquid-rich;2001-126_C_3FIA \\
\hline $2001-126$ & Quartz & $\mathrm{s}$ & 2 & $278.1-281.4$ & 279.8 & -1.4 to -1.1 & -1.3 & $1.9-2.4$ & 2.2 & Liquid-rich;2001-126_C_2FIA \\
\hline $2001-126$ & Quartz & $\mathrm{S}$ & 3 & $246.3-249.4$ & 247.8 & -0.9 to -0.6 & -0.8 & $1.1-1.6$ & 1.4 & Liquid-rich;2001-126_C_1FIA \\
\hline $2001-125$ & Quartz & $\mathrm{s}$ & 3 & $285.1-291.7$ & 289.2 & -1 to -1 & -1.0 & $1.7-1.7$ & 1.7 & Liquid-rich + illite;2001-125_III_2FIA_illite \\
\hline
\end{tabular}

$\mathrm{S}=$ secondary fluid inclusions; $\mathrm{P}=$ primary fluid inclusions; $\mathrm{T}_{h}=$ homogenization temperature; $\mathrm{T}_{m}=$ ice melting temperature; $\mathrm{n}=$ Umanibterenticated of fluid inclusions measured; ${ }^{1} \mathrm{Wt} \% \mathrm{NaCl}$ equiv from Bodnar [40] 


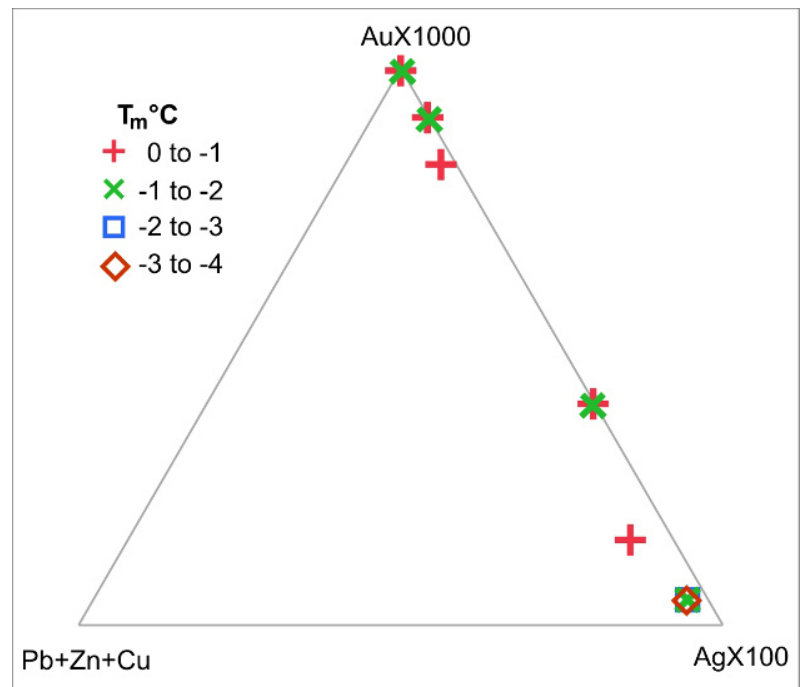

Figure 6. Ternary diagram showing Au-Ag-base metal ratios as a function of ice-melting temperature of fluid inclusions from the Santa Margarita Vein

Albinson [4] documented a clear correlation between fluid salinity and the metal budget of Mexican epithermal deposits. Fluids in gold-rich deposits generally have salinities < $3.5 \mathrm{wt} \% \mathrm{NaCl}$, whereas fluid salinities in Ag-rich deposits range up to about $7.5 \mathrm{wt} \%$, and $\mathrm{Ag}$-base metal epithermal deposits have salinities that extend up to about $23 \mathrm{wt} \% \mathrm{NaCl}$. In this study, all of the fluid inclusions have salinities $<5 \mathrm{wt} \%$. Some $\mathrm{Ag}$-rich samples have salinities $>2 \mathrm{wt} \% \mathrm{NaCl}$, but all of the Au-rich samples have salinities $<2 w_{t} \% \mathrm{NaCl}$ (Figure 6), consistent with earlier reports by Albinson [4]. The generally low salinity of all fluid inclusions in this study is consistent with previous studies that suggest that gold and silver are not transported as chloride complexes in the epithermal environment, but rather are transported as sulfide and/or hydroxyl complexes [4, 15-18].

For each of the gangue mineral textures and fluid inclusion characteristics described above for Santa Margarita vein samples, the average silver and gold grades for those samples containing the feature and for those samples not showing that feature were calculated (Figure 7). The feature that correlates most closely with high silver grades is the presence of trapped illite crystals in liquid-rich fluid inclusions. The fact that the illite is a trapped phase suggests that illite and a silica phase were co-precipitating in the vein, and that as the silica phase continued to precipitate it engulfed small illite crystals as the fluid inclusions formed. As shown on Figure 1, the $\mathrm{pH}$ at which illite and adularia are in equilibrium with quartz differs by about one log unit from the $\mathrm{pH}$ at which these min-

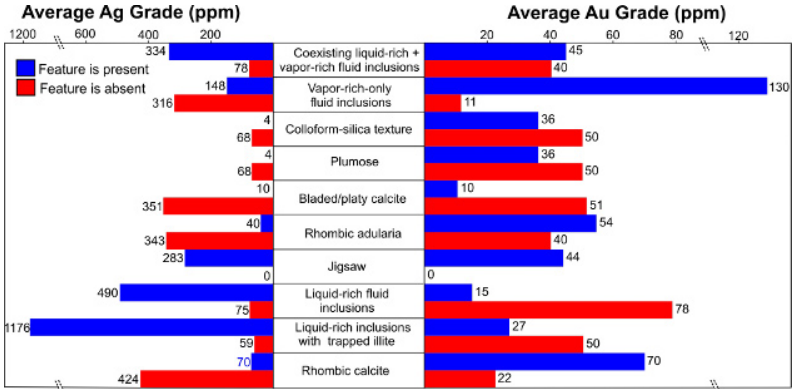

Figure 7. Relationship between average $\mathrm{Ag}$ and $\mathrm{Au}$ grades in samples from the Santa Margarita vein and the presence or absence of various mineral and fluid inclusion textures.

erals are in equilibrium with amorphous silica, and these phase boundaries straddle neutral $\mathrm{pH}$ at $250^{\circ} \mathrm{C}$. We also note that in most of the quartz veins in the Veta Madre, there is a trend from colloform texture quartz that gradually changes to coarse grained-quartz towards the vein center, ending in a well-formed euhedral quartz crystal. This textural evolution is repeated several times along a line from the vein wall to the vein center, and is interpreted to represent episodic and cyclic boiling of the hydrothermal fluid, whereby each cycle begins with rapid silica deposition as amorphous silica in response to boiling and, as boiling intensity decreases (or ends), coarser-grained quartz is deposited. Initial boiling deposits amorphous silica with a colloform texture, and as boiling intensity wanes the silica phase being deposited evolves towards chalcedony and finally to coarse quartz when boiling ends. Boiling may be terminated as the vein becomes sealed with silica and other phases, causing the pressure to increase until fracturing occurs with the release of pressure, leading to another phase of amorphous silica-chalcedonyquartz deposition. If illite is precipitating in equilibrium with quartz during a period of non-boiling (at slightly basic $\mathrm{pH}$ ), and then boiling begins with the precipitation of amorphous silica, the fluid will be driven to slightly acidic $\mathrm{pH}$. Thus, if a fluid is in equilibrium with illite-adulariaquartz and is at or near gold saturation, and the fluid $\mathrm{pH}$ rapidly evolves to be in equilibrium with illite-adulariaamorphous silica, gold solubility may be exceeded, leading to gold deposition. This is consistent with the fact that electrum is generally associated with colloform texture quartz and jigsaw texture quartz that are interpreted to have been precipitated from boiling fluids. If we assume that silver solubility relations are topologically similar to gold solubility relations shown on Figure 1, then silver may also be deposited as a result of boiling. This interpretation is consistent with experimental studies of gold and silver solubility $[17,18]$. 
The feature that correlates most closely with high gold grades is FIAs consisting of only vapor-rich fluid inclusions that are indicative of fluid flashing. Here we use the term flashing to indicate a condition whereby $100 \%$ of the liquid is converted to vapor as a result of decompression. We also emphasize that no vapor-rich only FIAs consisting of primary inclusions were observed, and this is consistent with the fact that during flashing amorphous silica is precipitated, and this phase does not trap (or record) primary inclusions. Buchanan [2] suggested that fluid flashing was an important mechanism for precious metals deposition in the deposits at Guanajuato, and a numerical modeling study by Cline [41] showed that isothermal flashing significantly enhances both silica deposition and gold precipitation, compared to the amounts that would be deposited by temperature decrease alone or by less intense boiling accompanied by temperature decrease. We therefore suggest that the presence of FIAs consisting of only vaporrich inclusions is consistent with flashing as the depositional mechanism for gold in the Santa Margarita vein at Guanajuato. These interpretations are reinforced by theoretical, experimental and field-based studies in active geothermal systems that document the close association of excessive boiling (i.e., "flashing") and gold and silver deposition [14, 17, 18, 21, 42].

\section{Summary}

Samples from the Santa Margarita Vein in the deep part of the Rayas Mine in the Guanajuato Mining District, Mexico, show a wide range in gangue mineral textures. Some of these textures, including colloform texture quartz, plumose texture quartz, jigsaw texture quartz and bladed calcite, are indicative of rapid precipitation, such as occurs when fluids boil. Other mineral phases, including illite and rhombic adularia are also characteristic of epithermal systems and are often associated with mineralization. Because boiling is an effective mechanism for precipitating gold and silver from hydrothermal fluids, the presence of mineral textures indicative of boiling is a desirable feature in exploration. In many samples, textural evidence for boiling is supported by coexisting liquid-rich and vaporrich fluid inclusions, or Fluid Inclusion Assemblages consisting of only vapor-rich inclusions, suggesting "flashing" of the hydrothermal fluids. The Santa Margarita samples show evidence of multiple boiling events based on either gangue mineral textural features observable in a hand sample or by detailed petrographic examination under the microscope. The clear relationship between these various features that are characteristic of boiling and elevated precious metals grades emphasizes the value of applying this technique in exploration. However, results of this study also show that no single monitor of boiling correlates well with $\mathrm{Ag}$ and $\mathrm{Au}$ grades, and all of the various boiling indicators should be monitored and assessed in determining whether boiling occurred and the intensity of the boiling event.

\section{Acknowledgments}

The authors thank the staff of Great Panther Silver Ltd, especially Robert Archer and Robert Brown for providing financial support and access to samples and information used in this study. Consejo Nacional de Ciencia y Tecnología (CONACyT) and the Virginia Tech Graduate School also provided partial funding during this study. We also thank Tawn Albinson and two anonymous reviewers of an earlier version of this manuscript for providing many useful suggestions and comments that have significantly improved the presentation.

\section{References}

[1] Moncada D., Mutchler S., Nieto A., Reynolds T.J., Rimstidt J.D., Bodnar R.J., Mineral Textures and Fluid Inclusion Petrography of the Epithermal Ag-Au Deposits at Guanajuato, Mexico. Application to Exploration, 2012, Journal of Geochemical Exploration (in press), DOI:10.1016/j.gexplo.2011.12.001

[2] Buchanan L.J., The Las Torres Mine, Guanajuato, Mexico; Ore controls of a fossil geothermal system, Colorado School of Mines, Golden, Colorado, 1979, PhD Thesis

[3] Great Panther Silver, Great Panther Discovers And Develops 3 New Zones At Guanajuato. News Releases, 2009 http://www.greatpanther.com/s/NewsReleases.asp? ReportID=411437\&_Type=News-Releases\&_Title $=$ Great-Panther-Discovers-And-Develops-3New-Zones-At-Guanajuato

[4] Albinson T., Norman D.I., Cole D., Chomiak B., Controls on formation of low-sulfidation epithermal deposits in Mexico; constraints from fluid inclusion and stable isotope data. Special Publication Society of Economic Geologists U. S., 2001, 8, 1-32

[5] Hedenquist J.W., Arribas R A., Gonzalez-Urien E., Exploration for epithermal gold deposits. Reviews in Economic Geology, 2000, 13, 245-277

[6] Roedder E., Fluid inclusions. Rev. Mineral., 1984, 12, 644

[7] Simmons S.F., White N.C., John D.A., Geological 
Characteristics of Epithermal Precious and Base Metal Deposits. Economic Geology $100^{\text {th }}$ Anniversary Volume, 2005, Economic Geology; One Hundredth Anniversary Volume, 1905-2005, 485-522

[8] Buchanan L.J., Ore controls of vertically stacked deposits, Guanajuato, Mexico. American Institute of Mining Engineers, 1980, Preprint 26, 80-82

[9] Kamilli R.J., Ohmoto H., Paragenesis, zoning, fluid inclusion, and isotopic studies of the Finlandia Vein, Colqui District, Central Peru. Econ. Geol., 1977, 72, 950-982

[10] Brown K.L., Gold deposition from geothermal discharges in New Zealand. Econ. Geol., 1986, 81, 979983

[11] Clark J.R., Williams-Jones A.E., Analogues of epithermal gold-silver deposition in geothermal well scales. Nature, 1990, 346, 644-645

[12] Etoh J., Izawa E., Watanabe K., Taguchi S., Sekine R., Bladed Quartz and Its Relationship to Gold Mineralization in the Hishikari Low-Sulfidation Epithermal Gold Deposit, Japan. Econ. Geol., 2002, 97, 18411851

[13] Weissberg B.G., Gold-silver ore-grade precipitates from New Zealand thermal waters. Econ. Geol., 1969, 64, 95-108

[14] Seward T.M., The hydrothermal chemistry of gold and its implications for ore formation; boiling and conductive cooling as examples. Economic Geology Monograph, 1989, 6, 398-404

[15] Helgeson H.C., Thermodynamics of hydrothermal systems at elevated temperatures and pressures. Am. J. Sci., 1969, 267, 729-804

[16] Shenberger D.M., Barnes H.L., Solubility of gold in aqueous sulfide solutions from 150 to $350^{\circ} \mathrm{C}$. Geochim. Cosmochim. Ac., 1989, 53, 269-278

[17] Stefànsson A., Seward T.M., Gold(I) complexing in aqueous sulphide solutions to $500^{\circ} \mathrm{C}$ at 500 bar. Geochim. Cosmochim. Ac., 2004, 68, 4121-4143

[18] Stefànsson A., Seward T.M., Experimental determination of the stability and stoichiometry of sulphide complexes of silver(I) in hydrothermal solutions to $400^{\circ}$ C. Geochim. Cosmochim. Ac., 2003, 67, 13951413

[19] Sillitoe R.H., Hedenquist J.W., Linkages between volcanotectonic settings, ore-fluid compositions, and epithermal precious metal deposits. Special Publication Society of Economic Geologists U. S., 2003, 10, 315343

[20] Gunnarsson I., Arnórsson S., Amorphous silica solubility and the thermodynamic properties of $\mathrm{H}_{4} \mathrm{SiO}_{4}^{\circ}$ in the range of $0^{\circ}$ to $350^{\circ} \mathrm{C}$ at $\mathrm{P}_{\text {sat }}$. Geochim. Cosmochim. Ac., 2000, 64, 2295-2307
[21] Brown K.L., Kinetics of gold precipitation from experimental hydrothermal sulfide solutions. Economic Geology Monograph, 1989, 6, 320-327

[22] Simmons S.F., Brown K.L., Gold in magmatic hydrothermal solutions and the rapid formation of a giant ore deposit. Science, 2006, 314, 288-291

[23] Simmons S.F., Brown K.L., The flux of gold and related metals through a volcanic arc, Taupo Volcanic Zone, New Zealand. Geology, 2007, 35, 1099-1102

[24] Prol-Ledesma R.M., Juarez-Sanchez F., LozanoSanta Cruz R., Alaca-Montiel E., Cruz-Casas V.A., Hernandez-Lombardini S., Canals A., Cardellach E., Precious and base metal deposition in an active hydrothermal system, La Primavera, Mexico. Proceedings - International Symposium on Water-Rock Interaction, 1998, 9, 649-652

[25] Bodnar R.J., Reynolds T.J., Kuehn C.A., Fluidinclusion systematics in epithermal systems. Reviews in Economic Geology, 1985, 2, 73-97

[26] Dong G., Morrison G., Jaireth S., Quartz textures in epithermal veins, Queensland; classification, origin and implication. Econ. Geol., 1995, 90, 1841-1856

[27] Fournier R.O., The behavior of silica in hydrothermal solutions. Reviews in Economic Geology, 1985, 45-61

[28] Sander M.V., Black J.E., Crystallization and recrystallization of growth-zoned vein quartz crystals from epithermal systems; implications for fluid inclusion studies. Econ. Geol., 1988, 83, 1052-1060

[29] Simmons S.F., Christenson B.W., Origins of calcite in a boiling geothermal system. Am. J. Sci., 1994, 294, 361-400

[30] Clark K.F., Foster C.T., Damon P.E., Cenozoic mineral deposits and subduction-related magmatic arcs in Mexico. GSA Bulletin, 1982, 93, 533-544

[31] Godchaux M.M., Bonnichsen B., Aguirre Diaz G.d.J., Aranda Gomez J.J., Rangel Solis G., Anonymous, Volcanological and tectonic evolution of a complex Oligocene caldera system, Guanajuato mining district, central Mexico. Abstracts with Programs - Geological Society of America, 2003, 35, 8

[32] Randall J.A., Saldana A E., Clark K.F., Exploration in a volcano-plutonic center at Guanajuato, Mexico. Econ. Geol., 1994, 89, 1722-1751

[33] Stewart M., Geology of Guanajuato and La Luz Areas, Mexico, 2006, Unpublished geologic map

[34] Taylor P.S., Mineral variations in the silver veins of Guanajuato, Mexico., Dartmouth College, Hanover, 1971, PhD Thesis

[35] Buchanan L.J., Precious metal deposits associated with volcanic environments in the Southwest. Arizona Geological Society Digest, 1981, 14, 237-262

[36] Great Panther Silver, Great Panther Silver Con- 
firms Continuity of Santa Margarita Gold-Silver Veins and Extends Guanajuatito Mineralized Zone to Depth at Guanajuato. News Releases, 2011 http://www.greatpanther.com/s/NewsReleases.asp? ReportID=493749\&_Type $=$ News-Releases\&_Title $=$ Great-Panther-Silver-Confirms-Continuity-ofSanta-Margarita-Gold-Silver-Vei...

[37] Goldstein R.H., Reynolds T.J., Systematics of fluid inclusions in diagenetic minerals. SEPM Short Course Notes, 1993, 31, 213

[38] Bodnar R.J., Introduction to fluid inclusions. Short Course Series, Mineralogical Association of Canada, 2003, 32, 1-8

[39] Sterner S.M., Bodnar R.J., Synthetic fluid inclusions in natural quartz; 1, Compositional types synthesized and applications to experimental geochemistry. Geochim. Cosmochim. Ac., 1984, 48, 2659-2668

[40] Bodnar R.J., Revised equation and table for determining the freezing point depression of $\mathrm{H}_{2} \mathrm{O}-\mathrm{NaCl}$ solutions. Geochim. Cosmochim. Ac., 1993, 57, 683-684

[41] Cline J.S., Bodnar R.J., Rimstidt J.D., Numerical simu- lation of fluid flow and silica transport and deposition in boiling hydrothermal solutions; application to epithermal gold deposits. J. Geophys. Res., 1992, 97, 9085-9103

[42] Simmons S.F., Browne P.R.L., Hydrothermal minerals and precious metals in the Broadlands-Ohaaki geothermal system: Implications for understanding low-sulfidation epithermal environments. Econ. Geol., 2000, 95, 971-999

[43] Henley R.W., Brown K.L., A practical guide to the thermodynamics of geothermal fluids and hydrothermal ore deposits. Reviews in Economic Geology, 1985, 2, 25-44

[44] Church J.A., The Mines of La Luz, Guanajuato, Mexico II. The Engineering and Mining Journal, 1907, 105110

[45] Wenxin L., Modeling description and spectroscopic evidence of surface acid-base properties of natural illites. Water Res., 2001, 35, 4111-4125 